\title{
THE EFFECT OF JIGSAW TECHNIQUE TO THE ENGLISH STUDENTS' READING IN READING ABILITY AT SECOND SEMESTER OF TEACHER TRAINING AND EDUCATION FACULTY OF UNIVERSITAS HKBP NOMMENSEN PEMATANGSIANTAR
}

\author{
Asima Rohana Sinaga \\ University of HKBP Nommensen Pematangsiantar \\ asimarohana.s@gmail.com
}

\begin{abstract}
Abstrak: Pembelajaran kooperatif bukanlah fenomena baru dalam proses belajar mengajar. Pembelajaran kooperatif memiliki banyak jenis teknik; salah satu tekniknya adalah jigsaw. Teknik jigsaw adalah model pembelajaran kooperatif yang terdiri dari beberapa anggota dalam satu kelompok yang bertanggung jawab atas materi pelajaran dan dapat mengajarkan topik tersebut kepada anggota kelompok lain, dengan kegiatan diskusi yang dapat membantu siswa untuk aktif di kelas. Tujuan dari penelitian ini adalah untuk mengetahui pengaruh teknik Jigsaw pada pemahaman membaca pada semester kedua dari Sekolah Pelatihan Guru di Universitas HKBP Nommensen Pematangsiantar. Peneliti menggunakan penelitian kuantitatif deskriptif yang dirancang dengan menerapkan desain Quasi-Eksperimental. Dalam melakukan desain ini, subjek penelitian dibagi menjadi dua kelompok: kelompok eksperimen dan kelompok kontrol. Perawatan ini hanya diperkenalkan pada subjek eksperimen. Kelompok eksperimen diperlakukan dengan menggunakan teknik Jigsaw sedangkan kelompok kontrol diperlakukan tanpa teknik Jigsaw. Subjek penelitian ini adalah kemampuan membaca siswa Bahasa Inggris pada semester kedua Fakultas Keguruan dan Ilmu Pendidikan Universitas HKBP Nommensen Pematangsiantar. Peneliti menggunakan ponsel sebagai instrumen yang merekam video kegiatan dosen dan siswa selama proses belajar mengajar di kelas. Hasil penelitian menunjukkan bahwa pada taraf signifikansi 5\%, nilai t-observ> t-table yaitu $(5,55>1,669)$. Dapat dikatakan bahwa t-mengamati lebih tinggi dari t-tabel. Jadi, hipotesis nol ditolak sementara hipotesis alternatif diterima. Dengan kata lain dapat disimpulkan bahwa penerapan teknik mengajar Jigsaw secara signifikan mempengaruhi kemampuan siswa dalam membaca pemahaman teks recount di Semester Kedua Pelatihan Guru dan Pendidikan Universitas HKBP Nommensen Pematangsiantar

Kata kunci: Efek, Teknik Jigsaw, Kemampuan Membaca
\end{abstract}

\begin{abstract}
Cooperative learning is not a new phenomenon in teaching learning process. Cooperative learning has many kinds of technique; one of the technique is jigsaw. Jigsaw technique is a cooperative learning model that consists of several members in one group that responsible for the lesson materials and be able to teach the topic to other member of group, by discussion activities which can help the students to be active in the class. The objective of this research is to find
\end{abstract}


The Effect of Jigsaw Technique to the English Students' Reading in Reading

Ability at Second Semester of Teacher Training and Education Faculty of

Universitas HKBP Nommensen Pematangsiantar out the effect of Jigsaw technique on reading comprehension at second semester of Teacher Training College in Universitas HKBP Nommensen Pematangsiantar. The researcher used descriptive quantitative research designed by applying Quasi-Experimental design. In conducting this design, the subjects of the research were divided into two groups: experimental group and control group. The treatment is introduced only to the experimental subject. The experimental group is treated by using Jigsaw technique while the control group is treated without Jigsaw technique. The subject of this research was The English students' reading in reading ability at second semester of Teacher Training and Education Faculty of Universitas HKBP Nommensen Pematangsiantar. The researcher used mobile phone as instrument which recorded video Lecturer and students activity during teaching and learning process in the class. The result of the research showed that in significance degree of $5 \%$, the value of t-observe > t-table that was $(5.55$ > 1.669). It could be said that t-observe was higher than $t$ table. So, the null hypothesis is rejected while the alternative hypothesis is accepted. In other words it can be concluded that the application of Jigsaw teaching technique significantly affects the students' ability in reading comprehension of recount text at Second Semester of Teacher Training and Education Faculty of Universitas HKBP Nommensen Pematangsiantar

\section{INTRODUCTION}

Keywords : Effect, Jigsaw Technique, Reading Ability
In learning language skills, students in University level, should have mastered four language skills, such as; reading, listening, writing and speaking. Reading, as one of the four language skills, is a critical academic skill, one which is necessary for success in all academic domains. Almost of all language test needs ability, which is the ability to read a text. In Nommensen University, students are taught the reading skill and is put as one of the subject practically include in the academic curriculum.

In this last two years this subject was changed from reading subject in to Intensive Reading subject. As the observation applied, it was found that the students were in fact get some difficulties in learning the subject. The students are difficult to gap the Vocabulary of the text, the students also difficult to comprehend the vocabularies, The students are difficult to point the main idea of each paragraphs, the difficulties result that low scores that this can be found from the data taken last semester. Related to the difficulties The Researcher assumes that The lecturer who taught the subject before still used the conventional technique and the lecturer who taught the subject didn't appropriate the technique well. The difficulties that the students face, The researcher proposing the Jigsaw technique can be very valuable to overcome the problem. It will be very interested to do this research as applying this technique on the intensive reading lecturing in the conception that the one of the second semester will get the higher score than the last semester. In addition that the government put higher that the students face, proposing the Jigsaw technique can be very valuable as two overcome the problem. It will be very interested to do this research as applying this technique on the Intensive Reading Lecturing in the conception that the one of the second semester will get the higher score than the last semester. In addition that the government put Higher Order Thinking Skills (HOTS) where the students are not only able to read but more than that comprehend the text. To solve the problems above, there are many techniques can be applied for teaching reading comprehension such as, Student 
The Effect of Jigsaw Technique to the English Students' Reading in Reading

Ability at Second Semester of Teacher Training and Education Faculty of

Universitas HKBP Nommensen Pematangsiantar

Team Achievement Division (STAD), Main

Mapping, Jigsaw, Problem Based Learning (PBL), etc. One of them is Jigsaw technique. Jigsaw technique is a cooperative learning model that consists of several member in one group that responsible for the lesson materials and be able to teach the topic to the member of group, by discussing activities which can help the students to be active in the class, such as; reading the text, hearing the teacher reading the text, get new w of vocabulary (Hyland, 2008). Jigsaw method makes it suitable for enhancing two essential and related teaching goals that contribute to reading comprehension: developing students metacognitive awareness, and learning the content while teaching it to peers in the small group (Meng, 2010:501-504).

Based on the explanation above, the researcher assumes that Jigsaw technique is suitable way to motivate students in reading. By using Jigsaw technique, they acquire basic knowledge. So, the researcher will conduct the research entitled "The Effect of Jigsaw Technique to the English Students' Intensive Reading Ability at second Semester of Teacher Training and Education Faculty of Universitas HKBP Nommensen Pematangsiantar.

\section{RESEARCH METHODHOLOGY}

\subsection{Research Design}

The research design used in this research is descriptive quantitative research design by applying Quasi-Experimental design. In conducting this design, the subjects of the research were divided into two groups: experimental group and control group. This research method is used to describe variables, to examine relationships among variables and to determine causeand-effect interactions between variables (Burns \& Grove, 2005:23). The treatment is introduced only to the experimental subject after measuring the two groups. The experimental group is treated by using Jigsaw technique while the control group is treated without Jigsaw technique. The test is given for each group and the average differences score are compered in order to certain whether the experimental treatment produce the greater change then the control group.

Table 3.1 Research Design

\begin{tabular}{l|l|l|l|} 
GROUP & PR & TREAT & PO \\
\hline
\end{tabular}

\begin{tabular}{|c|c|c|c|}
\hline & E- & MENT & ST \\
& TE & & TE \\
& ST & & ST \\
\hline EXPERIME & $\sqrt{ }$ & $\mathrm{X}$ & $\sqrt{ }$ \\
NTAL & & & \\
\hline CONTROL & $\sqrt{ }$ & $\mathrm{Y}$ & $\sqrt{ }$ \\
\hline
\end{tabular}

Note:

$\mathrm{X}$ : using Jigsaw technique

Y : using convensional technique

\section{RESEARCH FINDING}

\section{A. The Data Analysis}

The researcher took the scores from the students both of the control and experimental class. Herewith, the researcher gives the report concerning the data description of students' score of pre-test and post test.

\begin{tabular}{|c|c|c|c|c|c|c|c|}
\hline \multicolumn{3}{|c|}{$\begin{array}{l}\text { Students } \\
\text { Control Class }\end{array}$} & \multicolumn{3}{|c|}{$\begin{array}{l}\text { Students } \\
\text { Experimental } \\
\text { Class }\end{array}$} & \multicolumn{2}{|c|}{$\begin{array}{l}\text { Gaine } \\
\mathrm{d} \\
\text { Score } \\
\text { of } \\
\text { Contr } \\
\text { ol and } \\
\text { Experi } \\
\text { menta } \\
1 \text { Class }\end{array}$} \\
\hline $\begin{array}{l}\text { Stud } \\
\text { ents }\end{array}$ & $\begin{array}{l}\text { Pr } \\
\text { e- } \\
\text { Te } \\
\text { st }\end{array}$ & $\begin{array}{l}\text { Po } \\
\text { st- } \\
\text { Te } \\
\text { st }\end{array}$ & $\begin{array}{l}\text { Stu } \\
\text { den } \\
\text { ts }\end{array}$ & $\begin{array}{l}\text { Pr } \\
\text { e- } \\
\text { te } \\
\text { st }\end{array}$ & $\begin{array}{l}\text { Po } \\
\text { st- } \\
\text { Te } \\
\text { st }\end{array}$ & $\begin{array}{l}\mathrm{C} \\
\mathrm{o} \\
\mathrm{n} \\
\mathrm{tr} \\
\mathrm{o} \\
\mathrm{l}\end{array}$ & $\mathrm{E}$ \\
\hline $\begin{array}{l}\text { APS } \\
\text { S }\end{array}$ & 50 & 65 & $\begin{array}{l}\mathrm{A} \\
\mathrm{M}\end{array}$ & 20 & 70 & $\begin{array}{l}1 \\
5\end{array}$ & 50 \\
\hline $\begin{array}{l}\text { AP } \\
\mathrm{T}\end{array}$ & 25 & 50 & AS & 60 & 80 & $\begin{array}{l}2 \\
5\end{array}$ & 20 \\
\hline $\mathrm{AP}$ & 35 & 50 & BS & 45 & 75 & $\begin{array}{l}1 \\
5\end{array}$ & 30 \\
\hline $\begin{array}{l}\mathrm{AG} \\
\mathrm{N}\end{array}$ & 40 & 60 & CG & 30 & 75 & $\begin{array}{l}2 \\
0\end{array}$ & 45 \\
\hline DPS & 30 & 50 & DN & 20 & 70 & $\begin{array}{l}2 \\
0 \\
\end{array}$ & 50 \\
\hline $\begin{array}{l}\text { DA } \\
\text { S }\end{array}$ & 50 & 60 & $\begin{array}{l}\mathrm{D} \\
\mathrm{W}\end{array}$ & 60 & 85 & $\begin{array}{l}1 \\
0\end{array}$ & 25 \\
\hline CES & 45 & 55 & $\begin{array}{l}\text { ET } \\
\text { D }\end{array}$ & 45 & 70 & $\begin{array}{l}1 \\
0\end{array}$ & 25 \\
\hline FNS & 75 & 85 & $\begin{array}{l}\text { EP } \\
S\end{array}$ & 65 & 90 & $\begin{array}{l}1 \\
0\end{array}$ & 25 \\
\hline FN & 65 & 75 & EY & 65 & 80 & 1 & 15 \\
\hline
\end{tabular}


Asima Rohana Sinaga

The Effect of Jigsaw Technique to the English Students' Reading in Reading Ability at Second Semester of Teacher Training and Education Faculty of

Universitas HKBP Nommensen Pematangsiantar

\begin{tabular}{|c|c|c|c|c|c|c|c|}
\hline $\mathrm{T}$ & & & $\mathrm{H}$ & & & 0 & \\
\hline $\begin{array}{l}\mathrm{GV} \\
\mathrm{UA} \\
\mathrm{S}\end{array}$ & 50 & 60 & $\begin{array}{l}\text { FA } \\
N\end{array}$ & 30 & 70 & $\begin{array}{l}1 \\
0\end{array}$ & 40 \\
\hline GS & 70 & 75 & GS & 65 & 85 & 5 & 20 \\
\hline $\begin{array}{l}\text { GS } \\
W\end{array}$ & 50 & 70 & GS & 45 & 75 & $\begin{array}{l}2 \\
0\end{array}$ & 30 \\
\hline GA & 50 & 55 & HT & 75 & 80 & 5 & 5 \\
\hline JCP & 50 & 55 & $\begin{array}{l}\mathrm{IM} \\
\mathrm{ES}\end{array}$ & 65 & 80 & 5 & 15 \\
\hline JS & 40 & 65 & JP & 40 & 70 & $\begin{array}{l}2 \\
5\end{array}$ & 30 \\
\hline KM & 45 & 55 & JS & 50 & 70 & $\begin{array}{l}1 \\
0\end{array}$ & 20 \\
\hline $\mathrm{KS}$ & 45 & 60 & JD & 55 & 75 & $\begin{array}{l}1 \\
5\end{array}$ & 20 \\
\hline LH & 45 & 50 & $\mathrm{KS}$ & 60 & 85 & 5 & 25 \\
\hline $\begin{array}{l}\text { MW } \\
\text { S }\end{array}$ & 60 & 70 & $\mathrm{KN}$ & 45 & 80 & $\begin{array}{l}1 \\
0\end{array}$ & 35 \\
\hline $\begin{array}{l}\mathrm{MH} \\
\mathrm{S} \\
\end{array}$ & 45 & 60 & $\begin{array}{l}\mathrm{L} \\
\mathrm{MS} \\
\end{array}$ & 30 & 70 & $\begin{array}{l}1 \\
5 \\
\end{array}$ & 40 \\
\hline $\begin{array}{l}\text { MA } \\
\text { BB }\end{array}$ & 45 & 70 & $\begin{array}{l}M \\
G\end{array}$ & 45 & 70 & $\begin{array}{l}2 \\
5\end{array}$ & 25 \\
\hline $\mathrm{MH}$ & 65 & 75 & $\begin{array}{l}\text { MS } \\
\text { G }\end{array}$ & 50 & 75 & $\begin{array}{l}1 \\
0\end{array}$ & 25 \\
\hline MH & 55 & 70 & $\begin{array}{l}\mathrm{N} \\
\mathrm{M} \\
\mathrm{M}\end{array}$ & 75 & 80 & $\begin{array}{l}1 \\
5\end{array}$ & 5 \\
\hline PAP & 55 & 60 & $\begin{array}{l}\mathrm{NS} \\
\mathrm{S}\end{array}$ & 70 & 90 & 5 & 20 \\
\hline $\begin{array}{l}\text { RB } \\
\mathrm{D}\end{array}$ & 70 & 75 & $\mathrm{NS}$ & 20 & 75 & 5 & 55 \\
\hline RN & 65 & 85 & OP & 25 & 70 & $\begin{array}{l}2 \\
0\end{array}$ & 45 \\
\hline $\mathrm{RF}$ & 55 & 70 & $\begin{array}{l}\mathrm{O} \\
\mathrm{M}\end{array}$ & 60 & 80 & $\begin{array}{l}1 \\
5\end{array}$ & 20 \\
\hline
\end{tabular}

\begin{tabular}{|l|l|l|l|l|l|l|l|}
\hline & & & G & & & & \\
\hline RH & 25 & 45 & RE & 50 & 75 & 2 & 25 \\
& & & T & & 0 & \\
\hline SS & 60 & 70 & RS & 55 & 70 & 1 & 15 \\
\hline SH & 55 & 85 & SP & 45 & 75 & 3 & 30 \\
\hline SS & 55 & 70 & SS & 35 & 80 & 1 & 45 \\
\hline TP & 55 & 70 & SIS & 60 & 70 & 1 & 10 \\
\hline TG & 70 & 80 & SB & 30 & 90 & 1 & 60 \\
\hline VS & 70 & 85 & TH & 75 & 90 & 1 & 15 \\
\hline YS & 55 & 75 & TL & 45 & 70 & 2 & 25 \\
& & & A & & & 0 & \\
\hline ZTP & 45 & 70 & YS & 45 & 85 & 2 & 40 \\
& & & S & & & 5 & \\
\hline$\sum$ & 18 & 23 & $\sum$ & 17 & 27 & 5 & 10 \\
& 65 & 80 & & 55 & 80 & 1 & 25 \\
& & & & & & 5 \\
\hline Mea & 51, & 66 & Me & 48 & 72 & 1 & 28 \\
an & 81 &, 1 &, 7 &, 2 & 4 &, 4 \\
& & 1 & & 5 & 2 & 7 & 7 \\
& & & & & & 3 & 0 \\
\hline
\end{tabular}

\section{The T-test Score}

The descriptive analysis of T-test independent sample test

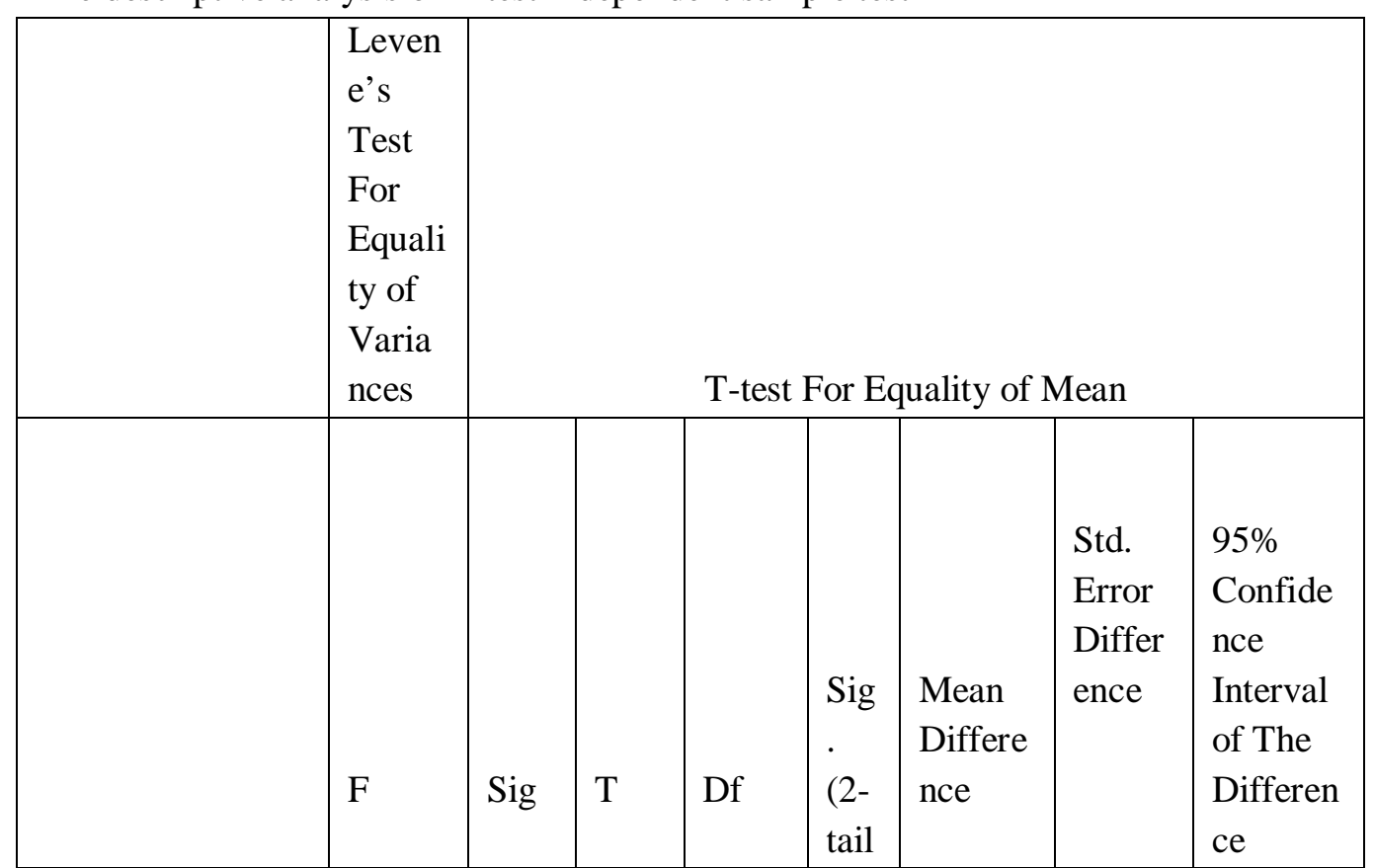


The Effect of Jigsaw Technique to the English Students' Reading in Reading

Ability at Second Semester of Teacher Training and Education Faculty of

Universitas HKBP Nommensen Pematangsiantar

\begin{tabular}{|c|c|c|c|c|c|c|c|c|c|}
\hline & & & & & ed) & & & & \\
\hline & & & & & & & & Lower & Upper \\
\hline $\begin{array}{l}\text { Equal } \\
\text { Variancies } \\
\text { Assumed } \\
\text { Equal } \\
\text { Variancies } \\
\text { Not } \\
\text { Assumed }\end{array}$ & $\begin{array}{l}13,81 \\
9\end{array}$ & ,000 & $\begin{array}{l}5,55 \\
4 \\
\\
\\
5,55 \\
4\end{array}$ & \begin{tabular}{|l}
70 \\
\\
\\
51,11 \\
5
\end{tabular} & $\begin{array}{l}, 00 \\
0 \\
\\
\\
, 00 \\
0\end{array}$ & $\begin{array}{l}14,166 \\
67 \\
\\
\\
14,166 \\
67\end{array}$ & $\begin{array}{l}2,550 \\
85 \\
\\
2,330 \\
85\end{array}$ & $\begin{array}{l}9,0791 \\
69,0459 \\
0\end{array}$ & $\begin{array}{l}19,25 \\
418 \\
\\
\\
19,28 \\
743\end{array}$ \\
\hline
\end{tabular}

Based on the table above, it shows that the result of the t-test from the experimental class and control class is 5,55. The table also showed that the degree of freedom (df) is 70 . The value level of significance is $0,05(5 \%)$ and 0,01 $(1 \%)$.

$t_{\text {table }}$ at $\mathrm{df} 70$ at $5 \%$ the level of significant $=1.669$

$t_{\text {table }}$ at $\mathrm{df} 70$ at $1 \%$ the level of significant $=2.385$

With the criteria:

If $t_{\text {teat }}\left(t_{\text {observed }}\right)>t_{\text {table }}$ Ha is accepted and Ho is rejected

If $t_{\text {tegt }}\left(t_{\text {obrgerved }}\right)<t_{\text {table }} \mathrm{Ha}$ is accepted and Ho is rejected

Based on the result of hypothesis calculation, it was found that the value of ( $t_{\text {observed }}$ ) was greater than the value of $t_{\text {table }}$ at the level of significance in $5 \%$ or $1 \%$ that was $1,669<5,55>2,385$. It means Ha was accepted and Ho was rejected

\section{B. Research Finding}

Based on the result on the data analysis showed that the use of jigsaw technique is good to improve the students, students reading comprehension ability. First, from the pre-test result, it can be gathered two findings, the mean of experimental group and the mean of the control group, the mean score of the experimental group is 48,75 , while the mean score of the control group is 51,81 . Both of those mean score are in the same category. From these results, it can be interpreted that the students of both group are passing equal intelligence. Second, based on the result on the post-test, it is found that there is an increase of the mean score of the experimental group and the control group. Nevertheless the increase of the mean score of the experimental group is higher than that of the control group. The increase of the mean score of the experimental group is 28,47 points. Meanwhile, the increase of the mean score of the control group is 14,30 points. The last according to the result of hypothesis test calculation, it was found that the value of $t_{\text {observed }}$ was greater than the value of $t_{\text {table }}$ at $5 \%$ and $1 \%$ the level of significance or $1,669<5,55>2,385$. It means that $\mathrm{Ha}$ was accepted and Ho was rejected.

\section{DISCUSSION}

Based on the research analysis the use jigsaw technique is good to improve the students' reading comprehension ability. The students are forced to understand the whole content of the text. The students are forced to analyze the specific information, the purpose, the topic, the main idea, etc of the text. The students also have to understand the context of the text. They have the responsibility to explain what they get to their friends. Unconsciously the students will be familiar on comprehending the text.

Furthermore, in order to answer the question the writer writes the alternative hypothesis ( $\mathrm{Ha}$ ) and the null hypothesis (Ho). To prove the hypothesis, the obtained in experimental class and control class are calculated by using t-test formula. It means that hypothesis alternative was accepted and null 
Kemampuan Menulis Teks Prosedur dengan Menggunakan Metode Resitasi pada Siswa Kelas VII SMP Negeri 40 Kabupaten Buru

hypothesis was rejected, and teaching reading of recount text by using jigsaw technique gives influences on the students' achievement of The English Students' Reading in Reading Ability At Second Semester of Teacher Training And Education Faculty Of University HKBP Nommensen Pematangsiantar.

\section{CONCLUSION}

Based on the result of the analysis, it showed that in significance degree of $5 \%$ the value of $\mathrm{t}$-observe $>\mathrm{t}$-table that was $(5,55>1.669)$. it could be said that $t-$ observe was higher than t-table. So, the null hypothesis is rejected while the alternative hypothesis is accepted. In other words it can be concluded that the application of jigsaw teaching technique significantly affects the students' ability in Intensive reading of recount text at second semester students of teacher training and education faculty of Universitas HKBP Nommensen Pematangsiantar.

The contribution after the researcher applied the jigsaw technique is the students more understanding purpose of the recount text, the structure of the recount text, and the linguistic element of the recount text.

\section{REFERENCES}

Alexander, L. G. 1997. Practice and Progress: An Integrated Course For Pre-intermediate Students. England: Langman.

Anderson, M and Anderson, K. 1997. Text Types in English 2. South Yarra: Macmillan.

Anderson, L. W. and Kratwohl, D. R. 2001. A Taxonomy for Learning, Teaching, and Assesing: A Revision of Bloom's Taxonomy of Education Objectives. Boston: Pearson Education Group.

Ary, D. 2010. Introduction to Research in Education. Belmont, CA: Davis.

Azijah, N. 2015. The Effectiveness of Jigsaw Toward Student's Reading Comprehension of Recount Text. Jakarta: English Department, Faculty of Tarbiya and Teachers' Training.

Boardman, A., Klinger, J. K., and Vaughn, S. 2008. Teaching Reading Comprehension to Students with Learning Difficulties. New York: The Guilford Press.
Bolukbas, F., Keskin, F., and Polat, M. 2011. The Effectiveness of Cooperative Learning (JigsawTechnique) on The Reading Comprehension Skills in Turkish as A Foreign Language. TOJET: The Turkish Online Journal of Educational Technology. Vol 10, Issue 4. Turkish.

Brassell, D. 2008. Enhancing English As A Second Language Students' Vocabulary Knowledge. Journal of Reading, Vol. 8, No. 1. The Reading Matrix Founded.

Brown, H. 2001. Teaching By Principle: An Interactive Approach to Language Pedagogy. (2nd ed). San Francisco: Addison Wesley Longman.

Burns, etl. 1984. Teaching Reading in Today's Elementary Schools. Boston: Houghton Miffin Company.

Burns, N. \& Grove, S. K. 2005. The Practice of Nursing Research: Conduct, Critique, and Utilization (5th Ed.). St. Louis: Elsevier Saunders.

Creswell, J. W. 2012. Planning, Conduct, and Evaluating Quantitative and Qualitative Rresearch. Boston: Pearson.

Evision, A. 1983. Oxford Learner's Pocket Dictionary New York: New York: Oxford University Press.

Gerot, L., and Wignell, P. 1994. Making Sense of Functional Grammar. Sydney: GerdStabler.

Hartono, R. 2005. Genre of text. Semarang: English Department, Faculty Of Language And Art, Semarang University.

Huebene. 2006. Total Participant Technique : Making every Student an Active Learners. United States of America: ASCD

Hyland, K. 2008. Cooperative Learning, Success for All, and Evidence based Reform in education. Éducation et didactique, Vol. 2, No. 2, pp.151-159. Varia.

Hyland, K. 2009. Academic discourse. London: Continuum

Hyland, K. 2009. Teaching and Researching Writing. Second 
Kemampuan Menulis Teks Prosedur dengan Menggunakan Metode Resitasi pada Siswa Kelas VII SMP Negeri 40 Kabupaten Buru

Edition. Great Britain: Pearson Education Limited.

Larasati, E. 2009. The Effect of Using Jigsaw Technique on Students' Reading Comprehension Achievement. Departman of English Education Faculty of Tarbiyah and Teachers' Training "Syarif Hidayatullah". Jakarta: State Islamic University.

Lenski, S., Lewis, J. 2008. Reading Success for Struggling Adolescent Learner. New York: The Guilford Press.

Lenz, K. 2005. An Introduction to Reading Comprehension. Available website:

http//www.specialconnections.ku. edu.// Retrieved on March 24th, 2018

Meng, J. 2010. Jigsaw Cooperative Learning in English Reading. Journal of Language Teaching and Research, Vol. 1, No. 4, pp. 501-504. Finland.

Nassanius. 2009. Reading Comprehension Strategies in Secondary Content Area Classrooms: Teacher Use of and Attitudes Towards Reading Comprehension Instruction. Edisi Desember, pp. 203-224

Ningsih, P. A. 2015. The Effectiveness of Teaching Writing Recount Text by using Facebook. Departman of English Education Faculty of Tarbiyah and Teachers' Training "Syarif Hidayatullah". Jakarta: State Islamic University.

Sapir, E. 1921. Language: An Introduction to the Study of Speech. New York: Jhon Hopkins University.

Saragih, S. 2015. Aplikasi SPSS dalam statistic Penelitian Pendidikan. Medan: Perdana Publishing.

Sihotang, I., and Purnawarna, P. 2015. The Effect of Jigsaw Stratagy To Improve Students' Skill in Writing a Recount Text. Journal of English Education, Vol. 3, Issue 2, pp 183-189.

Slavin, R. E. 1985. Learning to Cooperate, Cooperating to Learn. New York: Plenum.

Slavin, R. E. 1995. Cooperative Learning. International Encyclopedia of Teaching and Teacher Education, edited by Lorin, W. Anderson (2nd ed.), 139-143. UK: Cambridge University Press.

Slavin, R. 2008. Cooperative Learning and Academic Achievement: Why Does Groupwork Work?. Anales de Psicología, Vol. 30, No, 3.

Slavin, R. E. 2009. Educational Theory \& Practice. Boston: Longman.

Snow, C. 2002. Reading for

Understanding: Toward an R\&D Program in Reading Comprehension. Santa Monica, CA: RAND Corporation. 